\title{
Platinum-Sensitive Lung Small Cell
}

\section{Carcinoma}

National Cancer Institute

\section{Source}

National Cancer Institute. Platinum-Sensitive Lung Small Cell Carcinoma. NCI Thesaurus.

Code C158495.

Lung small cell carcinoma that is sensitive to platinum therapy. 